University of Wollongong

Research Online

Faculty of Social Sciences - Papers (Archive) Faculty of Arts, Social Sciences \& Humanities

2019

Cruel optimism? Socially critical perspectives on the obesity assemblage

Lisette Burrows

Deana Leahy

Jan Wright

University of Wollongong, jwright@uow.edu.au

Follow this and additional works at: https://ro.uow.edu.au/sspapers

Part of the Education Commons, and the Social and Behavioral Sciences Commons

Research Online is the open access institutional repository for the University of Wollongong. For further information contact the UOW Library: research-pubs@uow.edu.au 


\title{
Cruel optimism? Socially critical perspectives on the obesity assemblage
}

\author{
Abstract \\ Socially critical scholars in Health and Physical Education (HPE) have been raising questions about the \\ ethical, moral and social consequences of charging schools with the burden of ameliorating an 'obesity' \\ problem for years, yet there is little sign of any substantial shift in the thinking that drives obesity \\ strategies and policies in and around schools. Drawing on exemplars from our own and others' practice, \\ we interrogate the extent to which socially critical obesity work, and post-structural work, in particular, can \\ contribute to new understandings of the 'obesity assemblage'. Can our own repetitive aspirations to \\ disrupt dominant discourses be regarded as yet another exemplar of 'cruel optimism' or can a flourishing \\ body of critical enquiry actually do something both for young people in the context of health and physical \\ education and for cultural understandings more widely? \\ Disciplines \\ Education | Social and Behavioral Sciences \\ Publication Details \\ Burrows, L., Leahy, D. and Wright, J. (2019) Cruel optimism? Socially critical perspectives on the obesity \\ assemblage, in R. Pringle, G. Gerdin \& H. Larsson (eds) Critical research in sport, health and physical \\ education: How to make a difference. London: Routledge.
}


Lisette Burrows

School of Physical Education, Sport and Exercise Sciences

University of Otago, Dunedin

New Zealand

ORCID: 0000-0001-8706-1698

Deana Leahy

Faculty of Education

Monash University, Clayton 3800

Australia

ORCID: 0000-0002-3763-1573

Jan Wright

Faculty of Social Sciences,

University of Wollongong, Wollongong, NSW, 2522

Australia

ORCID: 0000-0003-0935-0915

Cruel Optimism? Socially critical perspectives on the obesity assemblage

\begin{abstract}
Socially critical scholars in Health and Physical Education have been raising questions about the ethical, moral and social consequences of charging schools with the burden of ameliorating an 'obesity' problem for years, yet there is little sign of any substantial shift in the thinking that drives obesity strategies and policies in and around schools. Drawing on exemplars from our own and others' practice, we interrogate the extent to which socially critical obesity work, and post-structural work, in particular, can contribute to new understandings of the 'obesity assemblage'. Can our own repetitive aspirations to disrupt dominant discourses be regarded as yet another exemplar of 'cruel optimism' or can a flourishing body of critical enquiry actually do
\end{abstract}


something both for young people in the context of health and physical education and for cultural understandings more widely?

\section{Introduction}

Childhood overweight and obesity concerns are relentlessly shaping what goes on in the name of Health and Physical Education globally (Burrows, 2010; Leahy \& Pike, 2015). For example in the US, Canada, Sweden, UK, Australia, New Zealand and Singapore both government and non government organisations as well as health promotion agencies point to schools as key sites that can effectively address the assumed 'obesity epidemic' through the incorporation of knowledge and pedagogies intended to change behavior in relation to healthy eating (eating less) and increasing physical activity.

On one hand, one could apply Berlant's (2011) notion of 'cruel optimism' to this endeavour, that is, those who place their hopes in health and physical education as the resolution to the problem of obesity, are firstly focusing on a utopia that is unachievable, and secondly, following Rasmussen (2015), are pursuing a utopia that distracts attention from important ethical, social and political questions such as health inequalities and the determinants of obesity (Leahy et al., 2016). We would also argue that while such efforts might not make a difference in reducing obesity or changing students' behaviours in the ways intended, they leave a damaging legacy, which cannot be ignored (e.g. weight-based oppression, victim blaming, discrimination, body hating, stigmatization, weight bias and so on). 
In other spaces, the notion of 'cruel optimism' has been applied to the endeavours of critical health educators to bring about change (see Leahy et al., 2016). As a general point, the idea that a critical approach to health education can overturn the juggernaut of the anti-obesity proponents, in the face of a culture that 'pathologises, insults and oppresses difference and fatness' (Aphramor 2005, p. 334), might also seem to be a form of cruel optimism. However, in this chapter we argue that it is both possible and necessary to take a stand, to engage in actions which counter/challenge obesity discourse and its associated practices. We argue that rather than distracting from important ethical, social and political questions, such questions need to be placed at the centre of our pedagogy as a means to redirect or upend the usual pedagogical forces that the obesity epidemic generates within HPE spaces (Burrows, 2016; Burrows \& Wright, 2004; Leahy, 2014, Pringle \& Pringle, 2012). We want to suggest that to not take a position is to ignore the damage that obesity discourse does and the political and moral circumstances in which it prevails.

To do this we look to Butler's (1993) notions of performativity alongside Deleuze and Guattari's concept of (de-)territorialisation. We are particularly interested in how such insights help us to disrupt the 'normal/the taken for granted. We argue that through [small] repetitive events/practices, the constant recitation of an alternative discourse, we may be able deterritorialise the hold of 'obesity' science/discourse in the political arena but also in everyday lives, in those places where obesity discourse takes hold and does damage. Through the recitation of an alternative, we can and have influenced health educators and health practitioners' practice by making visible the operation and effects of the discourse and making alternative ways of thinking possible. We want to suggest that such counter practices are important. Following 
Youdell (2011) we agree that schools also, and in our case, HPE spaces provide us with a significant spaces for the establishment of a counter politics (Leahy et al., 2016; Youdell, 2011).

We acknowledge the scepticism that has been levelled at such attempts to do critical work in the area of health education and obesity science. Indeed it has become something of a [necessary] trend in education and, for our purposes health and physical education, to interrogate the very notion of critique to ask: what constitutes a critical health education/physical education; does it do the work it purports to do; is it successful or, as Gard (2016) suggests, are critical obesity scholars generating a backlash and resistance through their advocacy of their own (often passionately held) position? This has prompted, we would argue, a healthy level of reflexivity, that hopefully addresses the simple 'us' and 'them' of the David and Goliath binary described by Gard (2011) in 'The End of the Obesity Epidemic'. As well as encouraging critical obesity scholars to 'make the limits of their political and moral motivations more transparent to themselves', Gard (2016, p. 248) argues for a pedagogical solution that emphasises the process of working with students - by 'offering resources for understanding' that demonstrate how 'truths' are uncertain and shifting and need to be interrogated.

In the following section we share two brief efforts to counter practices inspired by obesity knowledge and comment more specifically on other ways of dealing with 'the obesity assemblage' in the context of HPE. We do not regard any of our examples as exceptional, nor definitive examples of practices that will always facilitate alternate understandings. Rather, we are hopeful as Biesta (2005) is, that these efforts remind us that things can be different, that there are alternative ways of knowing and thinking about bodies, health and weight and that micro counter-practices can show 'that the way things were was only one limited possibility' (p. 155). 


\section{Every Body Counts}

Lisette was involved in a two year collaborative teaching and learning project where, with two colleagues (see Petrie et al., 2014), she sought to re-imagine possibilities for a primary school health and physical education that engaged diversely positioned children in a more inclusive and celebratory way. Four primary school teachers and three academics collaborated in this project that served to facilitate substantive shifts in both what was taught in HPE programs and how students learned (Ministry of Education, 2013). Below we briefly document what and who interrupted normative thinking throughout this project, signaling the critical moments or 'tipping points' that functioned to illuminate the effects of obesity discourse and provoke a desire to do and think in alternative ways.

For the teachers, it was the voices of children (some as young as 5 years of age), prompted by a series of individual and focus group interviews and a range of classroom activities as part of an 'environmental audit' that sowed seeds of doubt in relation to their existing practices. Hearing what their students believed about health and physical activity, why and from where they drew their current understandings, prompted personal reflections on the degree to which they had contributed to the entrenchment of oft-times narrow understandings of health, fitness and bodies. It also prompted cognizance of the ways outside matters (television advertisements, public health agendas, family proclivities and mass media campaigns) shape young people's sense of who they are and who they can become? 
The teachers were relatively unaware of the extent to which their students equated 'health' with particular body types (slim ones) and particular practices (eating the right foods and exercising a lot). They were similarly baffled by the almost exclusive equation of good health with matters of the body, despite their efforts to teach holistically and embrace the broader multi-faceted notion of health evident in the New Zealand Curriculum (Ministry of Education, 2007). Questions like, "what am I/ we doing that might contribute to my children thinking about being healthy and unhealthy in such narrow ways?", "what might it be like to be a child in my class/our school who doesn't really 'fit' these views of being healthy?", and "what could we do differently in HPE?", were raised in collective think-tank sessions.

For one of the teachers, questions like these prompted "a complete mind shift", a rethink of ideas and priorities she had previously held dear. For another, questioning common-sense orthodoxies provoked a keen awareness of how food and body messages were played out in friends' and families' homes and in the stories his own students told at sharing time. He recalled one 5 year old telling her teacher that she loved dancing and danced for hours at home. Her mother had told her she should keep on dancing as this would help her lose weight. These poignant moments coalesced to produce a shared understanding that as teachers, parents, friends, and siblings, we each contribute to how children make sense of food, bodies and health. The words we use in everyday conversations, the activities we choose to privilege and our willingness to simply accept the 'truth' of health messages that contour the lives of children were understood as all influencing how children might come to think of their own and others' health and physicality. 
For the project teachers and the academics, this recognition of the ubiquity of health messages fuelled a desire to critically interrogate orthodoxies and to find ways to enable students to also question what they were seeing and hearing about health and physical activity via new media, families, friends and public health messages. It also afforded a tipping point for reimagining what HPE could look and feel like in classrooms. After much discussion the research group came up with an 'ethos' - a series of 'touchstones' that reflected revised aspirations for Health and Physical Education in schools. In brief, this comprised the following principles. Children will:

. Know when, why and how to use knowledge in different contexts

- Understand notions of wellbeing that are holistic, multidimensional and interrelated

- Articulate, question and share multiple perspectives about being well

- Celebrate diversity

- Think critically about their world and accepted 'norms'. (Petrie et al., 2014)

Despite the resonance of the aforementioned tenets with the New Zealand Health and Physical Education in the New Zealand Curriculum, the project team realised that Health and Physical Education signals to many (both students and teachers) a fairly predictable suite of activities and ideas. Sports, fitness, healthy eating and fundamental motor skills, are just a few of the words both researchers and the 'public' associate with HPE (Tinning, 2010). Changing the name, we thought, might facilitate a change in ethos. If children didn't think they were 'doing HPE' they and their teachers may be more open to different ways of thinking about what the learning area is all about. EBC - Every-body Counts - worked as a label that captured the cornerstones of our 
ethos, emphasising our desire to create a version of HPE that was potentially inclusive of all, that is, all body types, all dispositions, all backgrounds, cultural affiliations, genders and proclivities.

While space does not permit a discussion of the pedagogies enacted en route to progressing this ethos, suffice to say that the voices of children, together with attentiveness to language and what this sediments were the pivotal resources needed to interrupt HPE 'as normal'. The recitation of an alternative name (EBC versus $\mathrm{HPE})$; the repetitive use of a different language to describe bodies, weight and well-being within and outside of classrooms; the openness to and commitment to changing curricula priorities and pedagogical norms upon recognition that old ways may be contributing to behaviours and dispositions in children that teachers found abhorrent, was enough to prompt a seismic change in the teachers positionings.

Perhaps it is primary teachers' positioning as people who 'care' for the well-being of children (Noddings, 2012), their unmitigated passion for ensuring teaching and learning meets the interests and needs of students, that permitted this somewhat dramatic shift in philosophical position and enacted pedagogy. As Tinning (2002) suggests, often HPE teachers regard themselves as saviours of young people in relation to obesity concerns, imagining themselves as obesity warriors (Burrows, 2016) who can and must endeavour to make students fitter and thinner via their pedagogies. In the case described above, the discomfort created by reflecting on what their students knew and how they came to know it, escalated the teachers' desire to 'save', but not from the perils of obesity. Rather, the teachers mobilised their discomfort, or, in Lather's (2006) terms, their 'distress' to re-build their own and their students' understandings about what matters in terms of health and well-being. The very relation of care and respect that prompted 
their initial engagement with obesity discourses drove their on-going attempts to challenge the latter.

\section{Poststructuralist interventions every day}

In a shift from school based pedagogical examples, we want also to include what might be loosely called serendipitous public pedagogical moments which point to the importance of the developing body of critical obesity scholarship as a resource to both expose and prise apart the various fractures and fissures that are an inherent part of any governmental assemblage (see Leahy, 2012; Youdell, 2011). Drawing on the poststructuralist notion that seemingly insignificant moments, micro claims and practices can do productive work in altering thinking about bodies and weight, we describe two pedagogical encounters with medics that we would argue from our experience (and the Fat Studies literature) are not isolated but represent an attempt by individuals directly impacted by obesity discourse to push back.

A prevalent theme across research studies and anecdotal reports is the phenomenon of doctors seizing opportunities (Gay, 2017; Phelan et al, 2015), no matter what the context, to lecture patients about weight-based matters. For example, one of us has a colleague who went to an eye specialist. Instead of gleaning information about her eyes, she was quizzed about how much she exercised and her daily eating habits. While one response might have been to acquiesce to her doctor's expertise, in this instance she re-positioned this distressing encounter as a pedagogical opportunity to educate her doctor. She challenged the doctor's assumptions that her body size and shape revealed anything about her lifestyle, queried the links drawn between weight and eye 
health, produced scholarly articles (including some of our own) for the doctor to read and engaged in on-going discussion about the discursive resources available to specialists when having clinical consultations with clients and the assumptions that drive deficit medical perceptions. An apology from the doctor, a commitment to reading, thinking and practice otherwise and reflection on the affect generated in such encounters ensued.

In another example, another of us received a 'thank you email' describing an experience with her doctor from whom she was seeking diagnostic advice about her weight and fat distribution. While space prohibits reproducing the entire email exchange here, with Mary's permission, we share a little of this encounter as it speaks directly to the capacity of weight-based discourse to shape medics' interactions with clients, but more importantly, the profound impact speaking back to this discourse (by drawing on critical obesity literature) can have in shifting sedimented perceptions. Her initial email reads:

Yes I have had another run in with a doctor. It is funny how if you are fat they seem to think you feel no pain or have no brain. But this encounter was really weird because up until now this doctor has treated me with respect heavens we even discussed literature... I have delivered the letter to the doctor's surgery and booked an appointment for next Tuesday. I will also be taking information of both your books to him. I hope this leads to a new understanding and a fresh start...

Mary D 
A section of the letter Mary sent is below:

Dear Dr $* * * *$,

I don't want to offend you but I need you to understand how I feel. If I seemed confused on Tuesday and had trouble expressing myself it was because I was trying to avoid tears. I am very sensitive to the subject of obesity as experience has taught me that the moment a doctor mentions my weight and goes straight to diet he/she no longer sees past my size meaning serious illness might go unnoticed or untreated. The fight or flight reaction kicked in and I became more stressed as the feelings of rejection increased. Ironically, having come to trust and respect you I had made the appointment specifically to discuss my weight and the unusual structure of the fat, on my abdomen and between my shoulders, which is possibly not entirely attributable to Lymphodema but I didn't have that opportunity.

It seemed to me that you did not believe me when I tried to outline my regular diet. To clear up any confusion: my diet mainly consists of lean meat, grilled fish, smoked salmon or six oysters, eggs (yolk removed after first egg) and various salad leaves (the dressing of which are sugar free and no fat, or plain lemon juice, or Balsamic vinegar) and seasonal vegetables steamed or stir fried in olive oil (mainly English spinach, fresh asparagus, capsicum, aubergine, microwaved mushrooms, spring onions, broccoli, celery etc). 
When you pulled up $<<$ http://www.sugarstacks.com/blog/> I felt it as an act of infantalization, as you had formerly treated me as an intelligent and cultured woman. No part of the picture blog, with its demonstration pile of white sugar cubes, applied to me. I do not consume fizzy drinks, fast food or processed foods nor do I eat pizza and would never darken the door of McDonalds or Kentucky fried because surprise, surprise, I am a very good cook and when I was slim and wealthy mostly dined at the finest restaurants in many parts of the world. I was staggered when you said I should replace fruit with a carrot. I eat one small serving of fresh fruit maybe once a day (raspberries, strawberries, red grapefruit, passionfruit etc and tomato) all of which are not much above the carrot in sugar content. I do not have bread, milk, sweets, cake or biscuits in the house. Items like the repellant tins of John West tuna, sardines or baked beans you suggested are quite foreign to my eating experience. $\cdots$

I really felt that stress on the way home when I recalled you saying to me "If you keep going this way you might be one of those people who have eventually to be removed from their house by a forklift truck (sic)" and tears started to roll down my face. Overcome by embarrassment, I fled to the shopping centre in a blur wanting to be comforted, I bought things I have not bought for years. For dinner on Tuesday night I fought against sorrow with two dozen oysters, an entire bottle of decent wine and a whole bar of chocolate. Bring on the forklift truck!

... I know more about weight and diet than most health workers because I live it. What I need is a doctor - I need you, Dr ****, I need the cultured man who reads books and I 
had come to respect. The doctor who treated me as an intelligent woman who was once a top flight journalist and award winning screenwriter, not merely a cretinous fat blob. Dr ****, I need you as a diagnostician, and it is there that you excel.

I will make another appointment. Do you think we could start again?

Mary D

The response from Mary's doctor reads"

Thanks for letting me know how badly I misjudged things with my attempted advice to you last week.

I fear I did not detect the cues that I was upsetting you.

I do remain worried about the medical effects of your build and the difficulties with hernia, heart disease etc but I will leave the subject alone unless there is a particular issue you want to raise.

I am very happy to continue with your general medical care if you wish. I would do my best but I can't promise always to get it right... 
The above pedagogical encounter scarcely needs analysis. Mary has done it herself. She succinctly conveys the affect her doctor produced. She helps him see how his weight-based paradigm impacts her subjectivity, her sense of herself as intelligent, creative, viable human. The visceral effects of his language are keenly realised in Mary's letter. The doctor's response signals at least, a recognition of this, and at most a promise to do and perhaps think differently with Mary and perhaps with other clients.

Both of the pedagogical encounters discussed above are discomforting ones -for the professional and client involved. Both involve the client drawing on sociological critiques of obesity to educate professionals and doing so from an initial position of vulnerability. Both women are educated in the traditional sense, hold prestigious positions in their chosen fields and have the intellectual resources, access to critical perspectives and resilience to challenge the hold of obesity science despite an initial desire to flee rather than stay. Clearly, these are not circumstances, nor resources that all would have access to. Nevertheless, harking back to our introductory comments, the recitation of an alternative discourse would seem to have deterritorialised, at least for a moment, the hold of obesity science in these two doctors' practice and thought. While Gard (2016) suggests asking uncomfortable questions as a key strategy in challenging obesity discourse, perhaps responding to uncomfortable questions is also a promising tactic for eliciting alternative ways of thinking.

\section{Discussion}


Despite the promises detailed in the encounters above, neither of the two examples above take on the obesity discourse head on as part of health knowledge within the HPE curriculum. In Australia and New Zealand, there are curriculum spaces that would allow educators to move beyond a 'health education' fuelled solely by public health obesity prevention discourses and practices (see for example the new Australian Curriculum: Health and Physical Education). The focus on an 'educative' purpose of health education and on critical inquiry, we would argue, makes it possible to disrupt/de-territorialise the hold of medicalised health promotion messages about obesity that are re-cited in school health education. The focus on an educative purpose makes it possible to pose the question: what might be possible if obesity became our object of critical study? In asking this question we follow Metzl's lead (2010) to think about the capacity of our classrooms to engage in a process that unpacks the concept of obesity from interdisciplinary perspectives and explore its assumptions, reliances and effects with our students. Within this space we could explore, for example, what particular meanings of obesity and associated practices impact people's lives, their bodies and their health. Such an approach requires 'deliberate interruptions' or what Evans et al (2011, p. 339) refer to as 'throwing a monkey wrench into a system of knowledge that perpetuates' the familiar and troubling practices of HPE'.

We recognise that there are limits to these possibilities both in schools and in teacher education. Recent research with HPE teacher education students, for example, suggests that despite their considerable enthusiasm to assist their students live healthier lives, this continues to be in the narrowest of terms, associated with risk-based approaches focusing on individual responsibility and behaviour change, despite health and physical education subjects which examine health from 
a critical perspective (Wright, O’Flynn \& Welch, 2017). We would also argue that in Australia at least, health and physical education teachers are often ill-prepared to teach outside the status quo, that is to teach about obesity as a socio-cultural phenomenon. The coupling of health and physical education means that those preparing to teach these subjects in secondary schools are required to take foundational subjects in anatomy and physiology and other science based subjects but not in the social sciences or humanities (see Leahy \& McCuaig, 2014; Wright et al., 2017). Yet the health knowledge they draw on and are expected to teach in an educative fashion, can best be understood, we argue, with some grounding in sociology and/or cultural studies. Such a grounding provides the tools to examine knowledge, including health knowledge as contingent, as shaped by social and historical circumstances, and with particular consequences for how people make sense of their bodies and their lives and those of others.

Given the substantial body of literature that points to the challenges of dealing critically with obesity knowledge in the context of schools and teacher education (Alfrey, O'Connor \& Jeanes, 2016; Burrows, 2016), we argue that there are other productive ways to disrupt the cultural assumptions associated with the multiplicity of interrelated knowledges and practices that comprise the 'obesity assemblage'. These include critical perspectives about obesity that reach the general public through public pedagogies in the form of museum based exhibitions, community arts based projects and performance poetry to name a few. For example, last year the Wellcome Collection in London, curated an exhibition entitled 'Obesity'. The exhibition was an attempt to include interdisciplinary voices that addressed the issue of obesity in some form. The exhibition included a sculpture [of an oversized obese, pink and fleshy body that dominated the room], various photographs, medical paraphernalia related to bariatric surgery in a glass case, 
nutrition advice, an installation that included a full ceiling to floor bookcase loaded up with diet books. Whilst the critical potential of the exhibition itself is the focus of ongoing research by Leahy, we want to highlight the possibilities that exhibition learning offers for engaging publics (including pre service teachers and school students) with interdisciplinary approaches. Whilst the 'usual suspects' were evident in the exhibition, i.e. medical and biomedical approaches, other spaces were indeed opened up for thinking 'otherwise'. For example, the sheer volume of diet books sitting on the enormous bookshelf evoked a visceral response in relation to the overwhelming profusion of advice that was on offer for a 'dieter' to feast upon. Picking up a phone to listen to fat activists and artists talk about fat and the body differently necessarily took the listener on a very different journey that moved us outside and away from biomedical and public health discourses. While it could be argued that more could have been done in the name of criticality within the exhibition space, the experience itself was enough to provoke a line of enquiry and thinking that is currently more difficult to provoke in school classrooms due to the dominance of particular kinds of knowledges and practices within HPE.

In addition to exhibitions, there is growing recognition of the potential of the arts, including theatre, performance and poetry to engage publics in questions related to how fat and obesity is portrayed, represented and culturally read (Mobely, 2014) ${ }^{\mathrm{i}}$. For example the performance poetry of English radical dietician and poet Lucy Aphramor. Aphramor (2016) tells us, in an overview of her work on her blog that:

Spoken word poems reach people in viscerally, pivotally different ways than any lecture or workshop ever could. Poems can hold stories that will always be too big, too rich, too unwieldy for an article. I use them to disturb the routine view on health that pretends there is no such thing as society. To 
disrupt the rules on what counts and whose voices matter. To share facts that have not had their soul ripped out with statistics. They do not assume a

single, static, sorted, standpoint, but - in short, they shake things up and this is the starting point for change.

Her performances engage the audience members in a process that critically identifies and purposefully disrupts deeply held beliefs that serve to maintain the obesity assemblage (see Aphramor, Gingras \& Morely, 2012). While critical pedagogues have for some time utilized these methods to gain critical leverage (see for example Goldstein, 2013; Huye, 2015), these forms are relatively new in the critical study of obesity in the HPE space (as an exception see Welch 2013, 2017). Given the above though we want to suggest that some potential exists and that such approaches may help us forge new directions. If obesity discourses, and the constellation of affects that accompany obesity prevention, are so intractable, perhaps recruiting new ways of working critically that make explicit attempts to work viscerally might help get us to a different place.

\section{References:}

Alfrey, L., O’Connor, J., \& Jeanes, R. (2017). Teachers as policy actors: co-creating and enacting critical inquiry in secondary health and physical education. Physical Education and Sport Pedagogy, 22 (2), 107-120.

Aphramor, L. (2016). Poet Lucy: Spoken Word Poet. Blog Available at: http://lucyaphramor.com/poet/about/ 
Aphramor, L. (2005). Is a weight - centred health framework salutogenic? Some thoughts on unhinging certain dietary ideologies, Social Theory \& Health, (3) 315-340.

Aphramor, L., Gingras, J., and Morely, C. (2012). Coming in from the Edgelands: Artist dietitians speak. 2nd Annual Critical Dietetics Conference, Sydney Australia.

Berlant, L., (2011). Cruel optimism. Durham, NC: Duke University Press

Berlant, L. (2010). Risky bigness: On obesity, eating and the ambiguity of health. In Johnathon Metzl \& Anna Krikland (Eds.), Against health: How health became the new morality. New York: New York University Press (pp. 26-39)

Burrows, L. (2010). Kiwi kids are Weetabix kids: Body matters in childhood, Sport, Education and Society, 15(2), 235-251.

Burrows, L. (2016). “Obesity” warriors in the tertiary classroom. In Erin Cameron and Constance Russell (Ed.), The fat pedagogy reader: challenging weight-based oppression through critical education (pp. 101-112) New York, NY, United States: Peter Lang.

Burrows, L. \& Wright, J. (2004). The good life: New Zealand children's perspectives of health and self. Sport, Education and Society, 9(2), 193-205 
Butler, J. (1993) Bodies that matter: On the discursive limits of 'sex'. New York and London: Routledge

Gard, M. (2011). The end of the obesity epidemic. Abingdon, Oxon, UK: Routledge,

Gard, M. (2016). Navigating morality, politics and reason: towards scientifically literate and intellectually ethical fat pedagogies. In Erin Cameron and Constance Russell (Ed.), The fat pedagogy reader: challenging weight-based oppression through critical education (pp. 241-250) New York, NY, United States: Peter Lang.

Gay, T. (2017) Hunger: A memoir of (my) Body. New York: Harper Collins.

Goldstein, T. (2013). Zero Tolerance and other plays: Disrupting racism, xenophobia and homophobia in school. Rotterdam, The Netherlands: Sense Publishers.

Huye, H. (2015). Using poetry and art analysis to evoke critical thinking and challenging reflection in senior-level nutrition students. Journal of Nutrition Education and Behavior, 47: 3, 283-285.

Lather, P. (2006) Paradigm proliferation as a good thing to think with: teaching research in education as a wild profusion, International Journal of Qualitative Studies in Education, 19:1, $35-57$. 
Leahy, D., 2014. Assembling a health[y] subject: risky and shameful pedagogies in health education. Critical Public Health, 24 (2), 171-181.

Leahy, D., \& McCuaig, L. (2014). Disrupting the field: Teacher education in health education. In K. Fitzpatrick \& R. Tinning (eds). Health education: Critical perspectives (pp. 220-232) London: Routledge.

Leahy, D., Burrows, L.,McCuaig, L., Wright, J. \& Penney, D. (2016) School health education in changing times: Policies, pedagogies and partnerships. London: Routledge.

Metzl, J. (2010). Introduction: Why against health? In: J Metzl and A. Kirkland, eds. Against health: How health became the new morality. New York: New York University Press. 1-11

Ministry of Education (2007). The New Zealand Curriculum. Wellington: Learning Media.

Mobely, J. (2014). Female bodies on the American stage: Enter fat actress. Palgrave MacMillan:

Noddings, N. (2012). The language of care ethics, Knowledge Quest, 40, 55, 52-56.

Petrie, K., Burrows, L. \& Cosgriff, M. (2014). Building a community of collaborative inquiry: a pathway to re-imagining practice in health and physical education. Australian Journal of Teacher Education 39(2). DOI: 10.14221/ajte.2014v39n2.3. 
Petrie, K., Burrows., Cosgriff, M. (2013). Everybody Counts? Reimagining Health and Physical Education in Primary Schools. Final Report. Wellington: Teaching and Learning Research Initiative.

Phelan, S.M. DJ Burgess, D.J. Yeazel, M. W., Hellerstedt, W. L., Griffin, J. M., \& van Ryn, M., (2015). Impact of weight bias and stigma on quality of care and outcomes for patients with obesity, Obesity Reviews, 16(4): 319-326.

Rasmussen, M.L. (2015). 'Cruel optimism and contemporary Australian critical theory in educational research. Educational Philosophy and Theory, 47(2), 192-206.

Tinning, R. (2010). Pedagogy and human movement: Theory, practice, research. London: Routledge.

Welch, R. (2013). Tracing contemporary healthscapes: Pre-service primary teachers' subjectivities in relation to health and the body (Unpublished doctoral thesis). University of Wollongong, NSW, Australia. Available URL:

http://ro.uow.edu.au/cgi/viewcontent.cgi?article=4791\&context=theses

Welch, R. (2017). Within and against each other: Comparative poetic vignettes as an analytic and educative tool in school health education, (Un)Making Europe: Capitalism, Solidarities, Subjectivities European Sociological Association (ESA) Conference, Athens URL: https://www.conftool.pro/esa2017/index.php?page=browseSessions\&form_session=1487 
Wright, J., O'Flynn, G. \& Welch, R. (2017) In search of the socially critical in health education: exploring the views of health and physical education preservice teachers in Australia, Health Education, http://www.emeraldinsight.com/doi/abs/10.1108/HE-11-2016-0060

Youdell, D. (2011). School trouble: Identity, power and politics in education. New York, NY:

Routledge.

${ }^{i}$ Additionally the journal Fat Studies has a special themed special issue in production at the time of writing this chapter entitled "Fat in Theatre Performance" 